Prevalensi Stunting Berdasarkan Kurva Standar WHO dan Kurva Referensi Pertumbuhan Anak Indonesia: Sebuah Studi Deskriptif di Kecamatan Blega

\title{
Prevalence of Stunting According to WHO Growth Standards and Indonesian Growth Reference Charts: A Descriptive Study from Blega Sub-District
}

\author{
Nafiys Hilmy ${ }^{1 *}$, Maitsa' Fatharani ${ }^{2}$
}

${ }^{1}$ Blega Primary Healthcare, Bangkalan, Indonesia

2Jagapura Primary Healthcare, Cirebon, Indonesia

\section{Article Info}

\section{Article History:}

Received: November 1, 2020

Accepted: December 30, 2020

Published: June 28, 2021

*)Corresponding author:

E-mail: reeventeergov@gmail.com

\section{How to cite this article:}

Hilmy, N., Fatharani, M. (2021). Prevalence of Stunting According to WHO Growth Standards and Indonesian Growth Reference Charts:A Descriptive Study from Blega Sub-District. Journal of Agromedicine and Medical Sciences, 7(2), 98-103. https://doi.org/10.19184/ams.v7i2.2386 $\underline{8}$

\begin{abstract}
Abstrak
Stunting merupakan salah satu masalah kesehatan yang telah dialami Indonesia sejak lama namun angka prevalensinya masih tetap tinggi dalam beberapa dekade belakangan. Terdapat dua jenis kurva pertumbuhan yang dapat digunakan dalam mendokumentasikan pertumbuhan seorang anak: kurva standar dan kurva referensi. Dalam beberapa tahun terakhir, pemilihan kurva pertumbuhan yang sesuai menjadi bahan perdebatan di berbagai negara. Tujuan penelitian ini adalah untuk membandingkan prevalensi stunting berdasarkan kurva standar pertumbuhan World Health Organization (WHOCGS) dan kurva referensi pertumbuhan anak Indonesia (INGRC). Data sekunder dari 2884 anak usia 0-59 bulan diperoleh dari rekapitulasi kegiatan 'Bulan Timbang' Februari 2020. Pengukuran nilai z-score panjang/tinggi badan terhadap usia dilakukan berdasarkan WHOCGS dan INGRC. Uji McNemar digunakan untuk membandingkan prevalensi stunting berdasarkan kedua kurva tersebut. Hasil penelitian menunjukkan prevalensi stunting pada anak usia bawah lima tahun di kecamatan Blega sebesar 11,16\% berdasarkan WHOCGS dan 5,83\% berdasarkan INGRC dengan p-value $<0.001$. Terdapat kelebihan dan kekurangan dari penggunaan masingmasing kurva pertumbuhan. Kesimpulan yang didapatkan prevalensi stunting dua kali lipat lebih rendah pada penggunaan INGRC dibandingkan dengan WHOCGS. Penelitian lebih lanjut tentang penggunaan kurva pertumbuhan yang tepat untuk untuk menggambarkan status gizi anak Indonesia sangat diperlukan untuk menunjang hasil penelitian ini.
\end{abstract}

Kata kunci: Stunting, kurva standar World Health Organization, kurva referensi pertumbuhan anak Indonesia

\begin{abstract}
Stunting is one of the remaining health issues in Indonesia and its prevalence was still high in the last decades. There are two types of growth charts that can be used in recording the child's growth: growth standards and growth references. In recent times, the selection of suitable growth charts has become a subject of discussion in many countries. This study aims to compare the prevalence of stunting according to the World Health Organization Child Growth Standards (WHOCGS) and Indonesian National Growth Reference Charts (INGRC) of children under five from the Blega sub-district. The secondary data from 2884 children were collected recapitulation of the 'Bulan Timbang' program in February 2020. Z-score of length/height-for-age was plotted according to WHOCGS and INGRC. McNemar test was used to compare the prevalence of stunting between both growth charts. The result showed that the prevalence of stunting in children under five from the Blega sub-district was 11,16\% according to WHOCGS and $5,83 \%$ according to INGRC with a p-value <0.001. There was an advantage and disadvantage when using both two growth charts. To conclude, the prevalence of
\end{abstract}


stunting was twofold lower using INGRC than WHOCGS. Further research about the suitable for representing child growth is still needed to support the result of this study.

Keywords: Stunting, World Health Organization Child Growth Standards, Indonesian National Growth Reference Charts.

\section{Pendahuluan}

Stunting didefinisikan sebagai panjang/tinggi badan seorang anak yang berada dibawah -2 standar deviasi (SD) atau persentil 3 grafik panjang/tinggi badan menurut usia (PB/U atau $\mathrm{TB} / \mathrm{U})$. Stunting menunjukkan adanya malnutrisi pada periode emas tumbuh kembang seorang anak, terutama di awal masa kehidupan (WHO, 2019). Stunting memiliki berbagai dampak buruk terhadap pertumbuhan dan perkembangan seorang anak (Stewart et al, 2013).

Terminologi stunting atau stunted merupakan istilah yang umum digunakan dalam konteks kesehatan masyarakat dan merujuk pada pertumbuhan linier yang terhambat atau terhenti karena faktor lingkungan terutama malnutrisi dan infeksi kronis (non endokrin). Sedangkan short stature merupakan istilah yang umum digunakan dalam konteks klinis untuk perawakan pendek tanpa melihat penyebabnya. Penyebab short stature terbanyak adalah stunting. Oleh karena itu, stunting merupakan bagian dari short stature, namun tidak semua short stature adalah stunting (IDAI, 2017). Berdasarkan data Riset Kesehatan Dasar Indonesia tahun 2018, persentase anak Indonesia usia bawah 5 tahun yang mengalami stunting (TB/U <-2SD) pada tahun 2007, 2013 dan 2018 secara berurutan adalah sebesar 36,8\%, 37,2\% dan 30,8\% (KEMENKES, 2018). Di Jawa Timur, persentase stunting tahun 2018 sebesar 38,2\%, sementara persentase di kabupaten Bangkalan sebesar 42\% (Balitbangkes, 2018). Kabupaten Bangkalan sendiri termasuk dalam satu dari 260 kabupaten/kota di Indonesia yang menjadi lokus prioritas program penurunan stunting tahun 2013-2019 dan juga termasuk dalam salah satu dari 100 kabupaten/kota prioritas tim Nasional percepatan penanggulangan kemiskinan untuk intervensi stunting tahun 2017/2018 (BPS dan KEMENKES, 2019; Tim Nasional Percepatan Penanggulangan Kemiskinan, 2017).

Terdapat dua jenis kurva yang dapat digunakan dalam mendokumentasikan pertumbuhan seorang anak: kurva standar dan kurva referensi. Kurva standar mendefinisikan bagaimana seharusnya seorang anak tumbuh. Sedangkan kurva referensi mendeskripsikan bagaimana seorang anak tumbuh pada waktu dan tempat tertentu (Pulungan, 2020). Dalam beberapa tahun terakhir, pemilihan kurva pertumbuhan yang sesuai menjadi bahan perdebatan di berbagai negara (Scherdel et al, 2015; Parsons et al, 2011; Scherdel et al, 2013). Dalam sebuah penelitian yang dilakukan pada 219 sampel negara, didapatkan 75\% menggunakan kurva standar World Health Organization/World Health Organization Child Growth Standards (WHOCGS) sebagai kurva pertumbuhan, $17 \%$ sedang mempertimbangkan, dan $7 \%$ tidak menggunakannya. Alasan utama tidak menggunakan WHOCGS adalah preferensi terhadap referensi lokal (De Onis et al, 2012). Selain itu, sebuah penelitian yang dilakukan di India tentang penggunaan WHOCGS, menunjukkan bahwa dengan penggunaan WHOCGS didapatkan lebih banyak anak stunting secara signifikan (Johnson et al, 2012). Hingga saat ini, penelitian yang membandingkan perbedaan antara WHOCGS dan kurva referensi pertumbuhan anak Indonesia/Indonesian National Growth Reference Charts (INGRC) masih sangat terbatas. Tujuan penelitian ini adalah untuk membandingkan prevalensi stunting berdasarkan WHOCGS dan INGRC pada anak usia bawah lima tahun di kecamatan Blega.

\section{Metode}

Penelitian ini merupakan penelitian observasional dengan metode cross-sectional yang dilakukan di kecamatan Blega, salah satu kecamatan di Bangkalan. Populasi penelitian ini adalah seluruh anak usia 0-59 bulan di kecamatan Blega dengan metode sampling yaitu total sampling.

Data yang digunakan merupakan data sekunder dari hasil rekapitulasi kegiatan 'Bulan Timbang' pada Februari 2020 (sebelum pandemi COVID-19 di Indonesia). Data panjang/tinggi badan dan berat badan didapatkan dari kegiatan Posyandu (Pos Pelayanan Terpadu). Data antropometri yang diperoleh kemudian diplot pada WHOCGS dan INGRC. Berdasarkan hasil plot pada kedua kurva pertumbuhan tersebut, didapatkan prevalensi stunting yang kemudian disajikan dan dianalisa secara deskriptif. Uji beda McNemar digunakan untuk membandingkan prevalensi stunting berdasarkan WHOCGS dan INGRC.

Penelitian ini telah disetujui oleh Komite Etik Fakultas Kesehatan Masyarakat Universitas Jember dengan persetujuan etik No.01/KEPK/FKM-UNEJ/II/2021 dan merunut pada pedoman etik Council for International Organization of Medical Sciences (CIOMS) 2016.

\section{Hasil Penelitian}

Terdapat 2884 anak usia bawah lima tahun yang berasal dari 19 desa di kecamatan Blega dengan jumlah yang hampir setara antara laki-laki dan perempuan. Lebih dari separuh sampel penelitian berusia 24-59 bulan (Tabel 1).

Tabel 1. Distribusi Sampel Berdasarkan Karakteristik Sampel

\begin{tabular}{lcc}
\hline Karakteristik Sampel & Jumlah $(\mathbf{n})$ & $\begin{array}{c}\text { Persentase } \\
\text { (\%) }\end{array}$ \\
\hline $\begin{array}{l}\text { Jenis kelamin } \\
\text { Laki-laki }\end{array}$ & 1464 & $50,76 \%$ \\
Perempuan & 1420 & $49,24 \%$ \\
\hline
\end{tabular}




\begin{tabular}{lcc}
\hline $\begin{array}{l}\text { Kelompok Usia } \\
\text { O-23 bulan }\end{array}$ & 1207 & $41,85 \%$ \\
24-59 bulan & 1677 & $58,15 \%$ \\
\hline $\begin{array}{l}\text { Desa Tempat Tinggal } \\
\text { Alas Rajeh }\end{array}$ & & \\
Bates & 207 & $7,18 \%$ \\
Blega & 235 & $8,15 \%$ \\
Blega Oloh & 335 & $11,62 \%$ \\
Gedungan & 53 & $1,84 \%$ \\
Gigir & 106 & $3,68 \%$ \\
Kajjan & 185 & $6,41 \%$ \\
Kampao & 166 & $5,76 \%$ \\
Karpote & 97 & $3,36 \%$ \\
Koolan & 140 & $4,85 \%$ \\
Karang Gayam & 50 & $1,73 \%$ \\
Karang Nangka & 199 & $6,9 \%$ \\
Karang Panasan & 172 & $5,96 \%$ \\
Lomaer & 143 & $4,96 \%$ \\
Lombang Dajah & 192 & $6,66 \%$ \\
Lombang Laok & 226 & $7,84 \%$ \\
Nyormanis & 87 & $3,02 \%$ \\
Panjalinan & 70 & $2,43 \%$ \\
Rosep & 42 & $1,46 \%$ \\
\hline
\end{tabular}

Berdasarkan WHOCGS, didapatkan prevalensi stunting sebesar $11,16 \%$. Sedangkan berdasarkan INGRC didapatkan prevalensi stunting sebesar 5,83\%. Pada penelitian ini, prevalensi wasted (indeks masa tubuh berdasarkan usia atau IMT/U) juga ditampilkan sebagai indikator lain dari malnutrisi (Tabel 2).

Tabel 2. Prevalensi Stunting dan Wasted Anak Usia Bawah Lima Tahun di Kecamatan Blega

\begin{tabular}{|c|c|c|c|c|}
\hline & Z-score & $\begin{array}{c}\text { WHOCGS } \\
\text { n (\%) }\end{array}$ & $\begin{array}{l}\text { INGRC } \\
\text { n (\%) }\end{array}$ & $\begin{array}{c}p- \\
\text { value }\end{array}$ \\
\hline \multirow{6}{*}{$\begin{array}{l}\mathrm{TB} / \\
\mathrm{U}\end{array}$} & $>3 S D$ & $367(12,73)$ & $463(16,05)$ & $<0.00$ \\
\hline & & & & $1 *$ \\
\hline & $\leq 3 S D \geq-2 S D$ & 2195 & $2253(78,12)$ & \\
\hline & & $(76,11)$ & & \\
\hline & $<-2 S D \geq-3 S D$ & $128(4,43)$ & $57(1,98)$ & \\
\hline & $<-3 S D$ & $194(6,73)$ & $111(3,85)$ & \\
\hline \multirow{6}{*}{$\begin{array}{l}\text { IMT } \\
/ \mathrm{U}\end{array}$} & $>3 S D$ & $32(1,11)$ & $26(0,9)$ & $<0.00$ \\
\hline & & & & $1 * *$ \\
\hline & $\leq 3 S D \geq-2 S D$ & 2397 & $2151(74,58)$ & \\
\hline & & $(83,11)$ & & \\
\hline & $<-2 S D \geq-3 S D$ & $259(8,98)$ & $423(14,67)$ & \\
\hline & $<-3 S D$ & $196(6,8)$ & $284(9,85)$ & \\
\hline
\end{tabular}

Uji beda McNemar

*p-value antara stunted (dan severely stunted) dan normal (-2SD lebih)

** $p$-value antara wasted (dan severely wasted) dan normal (-2SD lebih)

Berdasarkan prevalensi stunting pada anak usia bawah lima tahun di kecamatan Blega, didapatkan 322 anak digolongkan stunted ketika diukur menggunakan WHOCGS, dan 168 anak digolongkan sebagai stunted ketika diukur menggunakan INGRC. Tabel 3 menunjukkan distribusi anak-anak stunted tersebut berdasarkan jenis kelamin, kelompok usia dan indikator status gizi lain (berat badan terhadap usia atau BB/U dan IMT/U).
Tabel 3. Distribusi Karakteristik Sampel pada Anak Stunted

\begin{tabular}{lcc}
\hline Karakteristik & $\begin{array}{c}\text { Anak Stunted } \\
\text { (WHOCGS) } \\
\text { (N=322) } \\
\mathbf{n ~ ( \% ) ~}\end{array}$ & $\begin{array}{c}\text { Anak Stunted } \\
\text { (INGRC) } \\
\text { (N=168) } \\
\mathbf{n ~ ( \% ) ~}\end{array}$ \\
\hline $\begin{array}{l}\text { Jenis kelamin } \\
\text { Laki-laki }\end{array}$ & $164(50,93)$ & $81(48,21)$ \\
$\quad$ Perempuan & $158(49,07)$ & $87(51,79)$ \\
\hline Kelompok Usia & & \\
0-23 bulan & $123(38,2)$ & $62(36,9)$ \\
24-59 bulan & $199(61,8)$ & $106(63,1)$ \\
\hline Berat badan terhadap usia (BB/U) & \\
Normal & $123(38,2)$ & $51(30,36)$ \\
Underweight & $77(23,91)$ & $25(14,88)$ \\
Severely & $122(37,89)$ & $92(54,76)$ \\
$\quad$ underweight & & \\
\hline IMT terhadap usia $($ IMT/U) & \\
Normal & $284(88,2)$ & $144(85,71)$ \\
Wasted & $25(7,76)$ & $14(8,33)$ \\
Severely wasted & $13(4,04)$ & $10(5,95)$ \\
\hline
\end{tabular}

\section{Pembahasan}

Hasil penelitian di Kecamatan Blega menunjukkan bahwa prevalensi stunting berdasarkan pengukuran dengan INGRC lebih rendah dibandingkan pengukuran dengan WHOCGS. Beberapa penelitian di negara lain, seperti India (Khadilkar et al, 2010), Thailand (Hong et al, 2016), dan Argentina (Padula et al, 2012), yang membandingkan prevalensi stunting berdasarkan WHOCGS dan kurva referensi lokal negaranya masing-masing juga mendapatkan hasil yang serupa.

Saat ini hanya terdapat sedikit penelitian terpublikasi yang membandingkan perbedaan prevalensi berdasarkan WHOCGS dan INGRC. Pada penelitian yang dilakukan di Bandung (Novina et al, 2020), Jawa Barat, dan di Kecamatan Musi (Flynn et al, 2020), Nusa Tenggara Timur, menunjukkan bahwa prevalensi stunting berdasarkan INGRC lebih rendah dibandingkan WHOCGS. Kedua penelitian ini juga menyimpulkan bahwa INGRC lebih baik dalam merepresentasikan pertumbuhan anak Indonesia.

Beberapa faktor yang perlu diperhatikan dalam perbedaan angka prevalensi di antara kedua kurva tersebut adalah definisi stunting itu sendiri, kurva pertumbuhan yang digunakan, dan tren pertumbuhan sekuler (Galdeanoa et al, 2020). Perbedaan prevalensi yang mencolok pada penggunaan WHOCGS dan INGRC dapat disebabkan karena perbedaan metode dalam pengembangan kedua kurva tersebut. WHOCGS disusun berdasarkan data dari enam negara (USA, Brazil, Oman, Norwegia, Ghana, dan India) dengan kriteria inklusi yaitu anakanak sehat yang didukung dengan kondisi sosiodemografi yang sesuai dalam menunjang pertumbuhannya (Zorlu et al, 2011). Sehingga WHOCGS dijadikan sebagai kurva standar atau sebuah target yang diharapkan sekaligus mendeskripsikan bagaimana anak 'seharusnya tumbuh' di semua negara (Cole, 2012; WHO Multicentre Growth Reference Study Group, 2006). Sedangkan dalam penyusunan INGRC, tidak ada kriteria inklusi maupun eksklusi serta tidak dicantumkan kondisi 
sosiodemografi dan pola makan dari sampel yang terlibat sebagai sampel penelitian. Namun penyusunan kurva INGRC menggunakan data anak-anak dari 33 provinsi di Indonesia agar lebih mencerminkan pertumbuhan anak-anak Indonesia (Pulungan et al, 2018).

Terdapat sebuah penelitian di Eropa yang membandingkan penggunaan WHOCGS dan berbagai kurva referensi dari beberapa negara (Britania Raya, Perancis, Denmark, Republik Ceko, Belanda, Jerman, Norwegia, Swiss, dan Swedia) pada anak-anak short stature yang telah terindentifikasi etiologi dasarnya, seperti growth hormone deficiency (GHD), sindrom Turner dan born small for gestational age (SGA). Pada penelitian ini didapatkan hasil bahwa jumlah anak yang salah diklasifikasikan menggunakan WHOCGS secara signifikan lebih tinggi dibandingkan saat menggunakan berbagai kurva referensi lokal (regional/nasional) versi terbaru yang digunakan di berbagai negara tersebut. Namun penelitian ini juga mengungkapkan bahwa tidak ada kurva pertumbuhan yang sepenuhnya sensitif dan akurat dalam mengidentifikasi gangguan pertumbuhan (Christesen et al, 2016).

Penelitian yang dilakukan di Spanyol (Galdeanoa et al, 2020) dan China (Yang et al, 2015) menunjukkan bahwa angka prevalensi stunting berdasarkan kurva referensi lokal negara tersebut justru lebih tinggi dibandingkan pengukuran menggunakan WHOCGS. Pada penelitian di Spanyol (Galdeanoa et al, 2020), salah satu faktor yang dapat mengakibatkan perbedaan prevalensi tersebut adalah adanya akselerasi pertumbuhan sekuler yang terjadi di Spanyol dalam beberapa dekade terakhir. Sehingga pada pengukuran panjang/tinggi badan terhadap usia menggunakan WHOCGS dan kurva referensi lokal Spanyol versi lama akan didapatkan prevalensi stunting yang lebih rendah dibandingkan saat menggunakan kurva referensi lokal versi terbaru. Sedangkan pada penelitian di China, beberapa faktor yang mengakibatkan adanya perbedaan prevalensi tersebut diantaranya adalah perbedaan ukuran sampel penelitian, bayi cukup bulan yang lahir dengan berat badan kurang dieksklusikan dari sampel penelitian, serta pemberian ASI (Yang et al, 2015). Pada penelitian yang dilakukan pada anak-anak etnis Cina di Hongkong, didapatkan bahwa anak yang diberikan ASI, memiliki tinggi badan yang lebih tinggi dibandingkan dengan yang tidak mendapatkan ASI. Sehingga perbedaan prevalensi stunting pada kedua kurva tersebut, tidak hanya berkaitan dengan adanya variasi etnis (Hui et al, 2007).

Perdebatan tentang konsep stunting masih terus berjalan hingga saat ini. Salah satunya adalah konsep yang menyatakan bahwa malnutrisi dapat menyebabkan stunting, namun stunting bukan merupakan sinonim atau indikator utama dari malnutrisi (Scheffler et al, 2019). Penelitian ini dilakukan pada anak-anak di beberapa daerah rural Indonesia (Kupang, Nusa Tenggara Timur; Soe, Nusa Tenggara Timur; Ubud, Bali; dan Marbau, Sumatera Utara). Pada penelitian tersebut, tidak ditemukan adanya gejala kekurangan energi protein (KEP) pada anak yang didefinisikan sebagai stunting dan tidak ditemukan adanya perbedaan ketebalan lipatan kulit (sebagai penilaian status gizi) pada anak yang terpendek maupun yang tertinggi di populasinya. Hasil penelitian ini juga serupa dengan data yang didapatkan pada penelitian di Kecamatan Blega, dimana anakanak yang didefinisikan sebagai stunting hanya sebagian kecil yang mengalami wasted, $11,8 \%$ (WHOCGS) dan $14,28 \%$ (INGRC). Wasted merupakan salah satu tolak ukur adanya malnutrisi akut yang biasanya diakibatkan kurang asupan makanan atau penyakit berat (Pulungan, 2020). Scheffler et al (2019) juga mengusulkan identifikasi yang lebih presisi untuk menilai gagal tumbuh pada anak, sepeti kombinasi pengukuran tinggi badan, trisep, dan lipatan kulit subkapsular.

Namun terdapat sebuah argumen yang menkritisi tentang konsep tersebut. Argumen tersebut menyatakan bahwa pertumbuhan yang terhambat mungkin dimulai lebih awal sebelum anak-anak tersebut terdeteksi sebagai stunting. Sehingga pada anak-anak yang telah mengalami stunting, tidak lagi ditemukan tanda-tanda KEP ataupun infeksi. Argumen tersebut juga mengkritisi tentang anggapan penggunaan standar pertumbuhan WHO yang kurang tepat untuk mengidentifikasi stunting (Tanjung et al, 2020). Penggunaan kurva standar pertumbuhan merupakan lambang hak anak untuk mencapai potensi pertumbuhan genetiknya (De Onis et al, 2016).

Klasifikasi status gizi anak dipengaruhi kurva pertumbuhan yang digunakan (Galdeanoa et al, 2020). Hingga saat ini standar antropometri yang digunakan di Indonesia merujuk pada WHOCGS untuk anak usia 0-5 tahun dan The WHO Reference 2007 untuk anak 5-18 tahun (PMK No. 2 Tahun 2020). Sehingga perubahan kurva pertumbuhan yang digunakan sebagai acuan penilaian status gizi anak akan mempengaruhi mulai dari deteksi dini stunting hingga evaluasi program pemerintah untuk menekan angka stunting di Indonesia.

Saat ini pemerintah berencana membelanjakan jutaan dolar dalam rangka penanggulangan stunting di Indonesia, tetapi keyakinan bahwa status gizi dan kondisi kesehatan yang butuk mungkin menjadi penyebab utama stunting akan menyebabkan intervensi yang kurang tepat sasaran. Anakanak Indonesia secara signifikan memang lebih pendek dari standar/referensi yang disarankan oleh WHO. Hal ini yang menjadi latar belakang bahwa Indonesia membutuhkan kurva referensi pertumbuhan yang dapat membedakan secara jelas antara anak berperawakan pendek patologis dengan anak pendek lainnya, dan anak mana yang benar-benar membutuhkan intervensi medis atau nutrisi dengan anak sehat yang hanya dikategorikan pendek jika dibandingkan dengan referensi global. Kelompok tersebut tidak akan mendapat manfaat sekalipun diberikan intervensi (Pulungan et al, 2018).

Terdapat sebuah penelitian yang mengungkapkan bahwa anak-anak Indonesia yang hidup di era sekarang, sedikit lebih tinggi dibandingkan anak Eropa yang hidup berkecukupan di 150 tahun silam, namun lebih pendek jika dibandingkan dengan anak Eropa yang hidup di era sekarang. Beberapa faktor yang menyebabkan anak Indonesia yang hidup di era sekarang lebih pendek, diantaranya adalah kekurangan dalam infrastruktur sosial, ekonomi, politik dan psikologis. Selain itu kemiskinan, ketahanan pangan, dan trauma emosional juga berkaitan dengan stunting. Faktor-faktor tersebut di dunia 
modern barat, diketahui telah menunjang pertumbuhan anakanak Eropa untuk melampaui batas tinggi badan yang tercatat sebelumnya dalam sejarah. Nutirisi, status kesehatan, kondisi secara umum dan pengasuhan memang merupakan prasyarat yang esensial dalam pertumbuhan, tetapi hal ini saja tidak cukup untuk memaksimalkan pertumbuhan seorang anak (Scheffler et al, 2019).

Sebuah penelitian di India menduga bahwa overdiagnosis terhadap angka kejadian stunting saat penggunaan WHOCGS lebih sering terjadi di negara berkembang (Khadilkar et al, 2010). Hal ini merupakan salah satu kekurangan dari penggunaan kurva standar. Namun kurva standar memiliki kelebihan yaitu lebih objektif dan mudah untuk membandingkan pertumbuhan anak-anak antar negara, ras dan etnis. Sedangkan kurva referensi memiliki kelebihan yaitu benar-benar mewakili pola tumbuh kembang anak-anak yang ada pada suatu populasi sekaligus mempelajari adanya tren pertumbuhan sekuler pada populasi tersebut. Namun di sisi lain kurva referensi perlu diperbarui setidaknya sekali dalam satu dekade (Khadilkar dan Khadilkar, 2011).

Di Thailand, sebuah penelitian yang membandingkan status nutrisi anak kurang dari dua tahun, didapatkan hasil bahwa prevalensi stunting berdasarkan kurva referensi lokal lebih rendah dibandingkan WHOCGS dan penelitian tersebut menyimpulkan bahwa kurva referensi Thailand lebih merepresentasikan pertumbuhan anak-anak di Thailand. Namun peneliti tersebut juga mempertimbangkan penggunaan WHOCGS dalam rangka mengidentifikasi lebih banyak anak yang berisiko mengalami stunting (Hong et al, 2016).

Variasi yang ditemukan dalam berbagai penelitian menunjukkan fakta bahwa pertumbuhan dan pemantauan pertumbuhan adalah sebuah proses yang kompleks. Pertumbuhan itu sendiri dipengaruhi oleh gen, fisiologi, kondisi kesehatan, lingkungan, status gizi dan faktor terkait lainnya. Sedangkan dalam pemantauan pertumbuhan, dipengaruhi oleh perubahan tren pertumbuhan sekuler, ukuran setiap sampel penelitian dan komposisinya, kesalahan pengukuran dan lain sebagainya (Natale dan Rajagopalan, 2014). Tujuan melabeli anak-anak dengan stunting adalah untuk mendeteksi adanya potensi masalah kesehatan yang dapat menghambat pertumbuhan. Dengan mengingat hal ini, kita harus mempertimbangkan secara bijak apakah kita underdiagnosis ketika menggunakan kurva referensi atau overdiagnosis pada anak-anak yang sehat ketika menggunakan WHOCGS. Penelitian lebih lanjut sangat diperlukan untuk menunjang hasil penelitian ini.

\section{Kesimpulan}

Prevalensi stunting berdasarkan INGRC dua kali lipat lebih rendah dibandingkan pengukuran berdasarkan WHOCGS pada anak usia bawah lima tahun di Kecamatan Blega. Hasil penelitian ini diharapkan menjadi pemicu penelitian lain untuk mengkaji penggunaan kedua kurva ini dalam pengukuran status gizi anak Indonesia. Penelitian lebih lanjut tentang penggunaan kurva pertumbuhan yang tepat untuk menggambarkan status gizi anak Indonesia sangat diperlukan untuk menunjang hasil penelitian ini.

\section{Daftar Pustaka}

Badan Penelitian dan Pengembangan Kesehatan (Balitbangkes). (2019). Laporan Provinsi Jawa Timur Riskesdas 2018. Lembaga Penerbit Badan Penelitian dan Pengembangan Kesehatan. Jakarta

Badan Pusat Statistik (BPS) dan Kementrian Kesehatan RI. (2017). Laporan Pelaksanaan Integrasi Susenas Maret 2019 dan SSGBI tahun 2019. Badan Pusat Statistik. Jakarta

Christesen, H. T., Pedersen, B. T., Pournara, E., Petit, I. O., \& Júlíusson P.B. (2016). Short stature: Comparison of WHO and National Growth Standards/References for Height. PLoS ONE. 11(6): e0157277. https://doi. org/10.1371/journal.pone.0157277

Cole, T.J. (2012). The development of growth references and growth charts. Ann Hum Biol. 39:382-94. https://doi.org/10.3109/ 03014460.2012.694475

De Onis, M., \& Branca, F. (2016). Childhood stunting: a global perspective. Matern Child Nutr, 12:12-26. https://doi.org/ 10.1111/mcn.12231

De Onis, M., Onyango, A., Borghi, E., Siyam, A., Blössner, M., \& Lutter, C. (2012). Worldwide implementation of the WHO Child Growth Standards. Public Health Nutrition, 15(9), 1603-1610. https://doi. org/10.1017/S136898001200105X

Flynn, J., Alkaff, F. F., Sukmajaya, W. P., \& Salamah, S. (2020). Comparison of WHO growth standard and national Indonesian growth reference in determining prevalence and determinants of stunting and underweight in children under five: a cross-sectional study from Musi sub-district [version 3; peer review: 2 approved] .F1000Research, 9:324 https://doi.org/10.12688/f1000 research.23156.3

Galdeanoa, P. A., Abad, M. M., Alonsoa, A. A, Irureta S. J., Goikoetxea BC, Ruiz SG, et al. (2020). Effect of changing reference growth charts on the prevalence of short stature. An Pediatr (Barc). 92(1): 28-36. https://doi.org/10.1016/j.anpedi.2019.03.006

Hong, S. A., Mongkolchati, A., Chompikul, J., Mo-Suwan, L., \& Choprapawon, C. (2016). Comparison of prevalence of nutritional status of Thai children in the first 2 years of life using national and international growth charts. J Med Assoc Thai. 99 (1): 58-64. PMID: 27455825.

Hui, L. L., Schooling, C. M., Cowling, B. J., Leung, S. S., Lam, T. H., \& Leung, G. M. (2008). Are universal standards for optimal infant growth appropriate? Evidence from a Hong Kong Chinese birth cohort. Archives of disease in childhood, 93(7), 561-565. https://doi.org/10.1136/adc. 2007.119826

Ikatan Dokter Anak Indonesia (IDAI). (2017). Panduan Praktik Klinis Ikatan Dokter Anak Indonesia: Perawakan Pendek pada Anak dan Remaja di Indonesia. Badan Penerbit 
Ikatan Dokter Anak Indonesia. Jakarta

Johnson, W., Vazir, S., Fernandez-Rao, S., Kankipati, V. R., Balakrishna, N., \& Griffiths, P. L. (2012). Using the WHO 2006 child growth standard to assess the growth and nutritional status of rural south Indian infants. Annals of Human Biology 39(2):91-101. https://doi.org/10.3109/ 03014460. 2012.657680

Kementrian Kesehatan Badan Penelitian dan Pengembangan Kesehatan. (2018). Laporan Nasional Riskesdas 2018. Kemenkes RI. Jakarta

Khadilkar, V., \& Khadilkar, A. (2011). Growth charts: a diagnostic tool. Indian J Endocr Metab. 15(3): 166-171. https://doi.org/ 10.4103/2230-8210.84854

Khadilkar, V. V., Khadilkar, A. V., \& Chiplonkar, S. A. (2010). Growth performance of affluent Indian preschool children: a comparison with the new WHO growth standard. Indian Pediatr 47: 869-872. https://doi.org/10.1007/s13312-010-0147-6

Natale, V., \& Rajagopalan, A. (2014). Worldwide variation in human growth and the world health organization growth standards: a systematic review. BMJ Open. 4:e003735. https://doi.org/10.1136/ bmjopen-2013-003735

Novina, Hermasnussen, M., Schefffler, C., Pulungan, A. B., Ismiarto, Y. D., Andriyana, Y., et al. (2020). Indonesian National growth reference charts better reflect height and weight of children in West Java, Indonesia, than WHO child growth standards. J Clin Res Pediatr Endocrinol. 12(4):410-419. https://doi.org/10.4274/ jcrpe.galenos. 2020.2020.0044

Padula, G., Seoane, A. I., \& Salceda, S. A. (2012). Variations in estimates of underweight, stunting, wasting, overweight and obesity in children from Argentina comparing three growth charts. Public Health Nutr. 15(11): 2086-2090. https://doi.org/ 10.1017/S136898001200095X

Parsons, H. G., George, M. A., \& Innis, S. M. (2011). Growth Assessment in clinical practice: whose growth curve? Curr Gastroenterol Rep. 13:286-292 PLoS ONE 8(8): e70871. https://doi.org/ 10.1007/ s11894-011-0187-7

Peraturan Menteri Kesehatan. (2020). Peraturan Menteri Kesehatan (PMK) Republik Indonesia Nomor 2 Tahun 2020 Tentang Standar Antropometri Anak.

Pulungan, A. B. (2020). Auxology, Kurva Pertumbuhan, Antropometri, dan Pemantauan Pertumbuhan. Sari Pediatri 22(2):123-130. http://dx.doi.org/10.14238 /sp22.2.2020.123-30

Pulungan, A. B., Julia, M., Batubara, J. R. L, \& Hermanussen, M. (2018). Indonesian National Synthetic Growth Charts.
Acta Scientific Paediatrics. 1.1: 20-34.

Scheffler, C., Hermanussen, M., Bogin, B., Liana, D. S., Taolin, F., Cempaka, P., et al. (2019). Stunting is not a synonym of malnutrition. Eur J Clin Nutr. 74:377-386. https://doi. org/10.1038/s41430-019-0439-4

Scherdel, P., Botton, J., Rolland-Cachera, M-F., Léger, J., Pelé, F., Ancel, P. Y., et al. (2015). Should the WHO growth charts be used in France? PLOS ONE 10(3): e0120806. https://doi.org/10.1371/journal.pone.0120806

Scherdel, P, Salaün, J. F., Robberecht-Riquet, M. N., Reali, L., Páll, G., Jäger-Roman, E., et al. (2013). Growth monitoring: a survey of current practices of primary care paediatricians in Europe. Plos ONE 8(8): e70871. https://doi.org/10.1371/journal. pone.0070871

Stewart, C. P., lannotti, L., Dewey, K. G., Michaelsen, K. F., \& Onyango, A. W. (2013). Contextualising complementary feeding in a broader framework for stunting prevention. Matern Child Nutr. 9:27-45. https://doi.org/10.1111/ mcn. 12088

Tanjung, C., Prawitasari, T., \& Sjarif, D. R. (2020). Comments on "Stunting is not a synonym of malnutrition". Eur J Clin Nutr. 74, 527-528. https://doi.org/10.1038/s41430-0200570-2

Tim Nasional Percepatan Penanggulangan Kemiskinan. (2017). 100 Kabupaten/Kota Prioritas untuk Intervensi Anak Kerdil (Stunting): Ringkasan. Sekretariat Wakil Presiden Presiden Republik Indonesia. Jakarta

World Health Organization (WHO). (2015). Nutrition: Stunting in a nutshell. https://www.who.int/nutrition/healthy growthproj_stunted_videos/en/ (diupdate 19 November 2015; diakses pada 15 Januari 2021).

World Health Oorganization (WHO) Multicentre Growth Reference Study Group. (2006). Assessment of differences in linear growth among populations in the WHO Multicentre Growth Reference Study. Acta Paediatr. Supp 450:56-65. https://doi.org/ 10.1111/j.1651-2227.2006.tb02376.x

Yang, Z., Duan, Y., Ma, G., Yang, X., \& Yin S. (2015). Comparison of the China growth charts with the WHO growth standards in assessing malnutrition of children. BMJ Open. 5(2): e006107. https://doi.org/ 10.1136/bmjopen2014-006107

Zorlu, G. (2011). New WHO child growth standards catch on. Bull World Health Organ. 89(4): 250-1. https://doi.org/ 10.2471/BLT.11.040411 